\title{
Implementation of information technology on the publication and promotion of mangrove eco-tourism in Sisarahili, Teluk Siabang village
}

\author{
Esther Sorta Mauli Nababan ${ }^{1 *}$, Nelson Manumpak Siahaan ${ }^{2}$, Agus Salim Harahap ${ }^{1}$, Pramio \\ Garson Sembiring ${ }^{3}$, Meyman Sokhi Ziliwu ${ }^{4}$, \\ ${ }^{1}$ Departments of Mathematics, Faculty of Mathematics and Natural Science, Universitas \\ Sumatera Utara \\ ${ }^{2}$ Departments of Architecture, Faculty of Engineering, Universitas Sumatera Utara \\ ${ }^{3}$ Departements of Mechanical Engineering, Faculty of Engineering, Universitas Sumatera \\ Utara \\ ${ }^{4}$ Departments of Technic Informatics, Faculty of Computer Science and Information \\ Technology, Universitas Sumatera Utara \\ *Email: esther@usu.ac.id
}

\begin{abstract}
The mangrove forests that stretch along the coast of the Nias islands have great potential to improve the economy of the surrounding communities. One of the largest and most extensive mangrove areas is in Ba'a bay, located in Sisarahili bay, Siabang village, Sawo District, North Nias Regency. Mangrove forest turns out to be a natural resource and tourism potential that is crowded with visitors, supported by its existence in a wide stretch of coastline. However, the development of tourism potential still needs to be done to further increase the arrival of both domestic and foreign tourists. Several things have been done to support increased publication and promotion by increasing the human resources of tourism awareness groups through training and workshops, improving facilities and infrastructure, transportation and accommodation and also the application of information technology media to maximize publication and promotion, so that visitors are not only local people but also from outside the region. The use of page-based information technology and social media as media is implemented to support publication and promotion in accordance with the results of a survey conducted by the community service team for visitors who come. As many as $65 \%$ of visitors get information about mangrove tourism in Teluk ba'a from printed social media and $15 \%$ from websites / pages, while $20 \%$ get information from friends, online newspapers and communities around the mangrove tourism environment.
\end{abstract}

Keyword: Information Technology, Social Media, Ekowisata Mangrove, Human Resources

\begin{abstract}
Abstrak
Hutan mangrove yang membentang disepanjang pantai kepulauan Nias memiliki potensi yang besar untuk meningkatkan ekonomi masyarakat disekitarnya. Salah satu daerah mangrove yang terbesar dan terbentang luas ada di teluk Ba'a tepatnya di Desa Sisarahili Teluk Siabang Kecamatan Sawo Kabupaten Nias Utara. Hutan mangrove ternyata merupakan sumber daya alam dan potensi wisata yang ramai dikunjungi, didukung oleh keberadaannya digaris pantai yang membentang luas. Namun pengembangan potensi wisata masih harus dilakukan untuk lebih meningkatkan kedatangan wisatawan baik domestik maupun mancanegara. Beberapa hal yang sudah dilakukan untuk mendukung peningkatan publikasi dan promosi dengan peningkatan SDM kelompok sadar wisata melalui pelatihan dan workshop, perbaikan sarana dan prasarana, transportasi dan akomodasi dan juga penerapan media teknologi informasi untuk memaksimalkan publikasi dan promosi, sehingga pengunjung bukan hanya masyarakat lokal tetapi juga ada yang berasal dari luar kota. Penggunaan teknologi informasi berbasis laman dan sosial media sebagai media diterapkan untuk mendukung publikasi dan promosi sesuai dengan hasil survey yang dilakukan oleh tim pengabdian masyarakat bagi pengunjung yang datang. Hasil survey menunjukkan bahwa sebanyak $65 \%$ pengunjung mendapatkan informasi tentang wisata mangrove teluk Ba'a dari sosial media cetak dan $15 \%$ dari website/laman, sedangkan $20 \%$ lainnya mendapatkan informasi dari teman, koran online dan masyarakat di sekitar lingkungan wisata mangrove.
\end{abstract}

Kata Kunci: Teknologi Informasi, Media Sosial, Ekowisata Mangrove, Sumber Daya Manusia 


\section{PENDAhUluan}

Sumber daya alam di wilayah pesisir adalah mangrove ditinjau dari fungsi fisik, ekonomi dan ekologi (F Guebes et al., 2005). Menurut (Lalo, 2003), Ekosistem mangrove merupakan salah satu tipe ekosistem yang unik, oleh karena hidup dalam dua karakteristik ekosistem yaitu darat dan laut sehingga mengakibatkan jenis biota yang hidup di habitat mangrove terdiri dari biota laut dan biota darat. Luasan ekosistem mangrove semakin berkurang akibat tekanan dari berbagai aktivitas manusia yang semakin banyak, serta perluasan kota yang semakin pesat. Pemanfaatan yang tidak diiringi dengan pelestarian yang bijaksana dikhawatirkan akan menyebabkan penurunan sumberdaya, bahkan menyebabkan kepunahan. Dalam kurun waktu 11 tahun hutan mangrove di Indonesia telah mengalami degradasi sekitar $13 \%$ atau sekitar 515761 ha (DV, 2010). Pada Tahun 2005 terjadi gempa di Kepulauan nias yang berdampak pada penyusutan air laut sehingga luas daratan di sekitar pinggiran pantai mengalami peningkatan. Dampak peningkatan luas daratan di sekitar pinggiran pantai menyebabkan tanaman mangrove yang seharusnya berada di air laut lama kelamaan mengalami kerusakan. Penduduk yang tinggal di sekitar lokasi mangrove juga menggunakan mangrove ini berlebihan tanpa pengelolaan yang baik sehingga tanaman mangrove dari tahun ke tahun menurun drastis. Kerusakan ekosistem mangrove dampak dari gempa yang terjadi, konversi lahan ekosistem mangrove oleh masyarakat untuk pemanfaatan lahan dengan tanaman lainnya serta penebangan pohon mangrove yang digunakan masyarakat untuk kebutuhan kayu bakar. Pemerintah Daerah Kabupaten Nias Utara memberikan dukungan penuh untuk pengembangan potensi daerah. Renstra Nias Utara melalui Dinas Pariwisata dan Kebudayaan memprioritaskan dalam pengembangan mangrove yang sudah banyak mengalami kerusakan. Kesungguhan pemerintah daerah sudah mulai dengan merencanakan pembangunan akses melalui infrastruktur sehingga mudah untuk mencapai mangrove yang tingkat kerusakannya tinggi.

Kabupaten Nias Utara adalah salah satu kabupaten yang terletak di Kepulauan Nias, Provinsi Sumatera Utara, yang merupakan pemekaran dari Kabupaten Nias pada tahun 2008. Sebagian besar wilayahnya berada di pesisir, sehingga memiliki garis pantai yang panjang. Kecamatan Sawo termasuk dalam wilayah Kabupaten Nias Utara dan memiliki ekosistem mangrove yang lebih luas dibandingkan dengan kecamatan lainnya. Pantai Utara Pulau Nias terdapat 25 (dua puluh lima) jenis mangrove yang termasuk dalam 13 (tiga belas) suku dengan cakupan luas mangrove sebesar 4,54 Km2 terdapat di Desa Sisarahili Teluk Siabang, Kecamatan Sawo, terdapat 15 jenis mangrove; 12 diantaranya adalah mangrove sejati serta 3 (tiga) lainnya merupakan mangrove ikutan (Zai et al., 2014). Penelitian lain yang dilakukan di Desa Lasara Sawo, Kecamatan Sawo, menunjukkan terdapatnya 10 (sepuluh) spesies mangrove; enam di antaranya merupakan mangrove sejati dan empat yang lainnya merupakan mangrove ikutan (Mendrofa, 2014). 


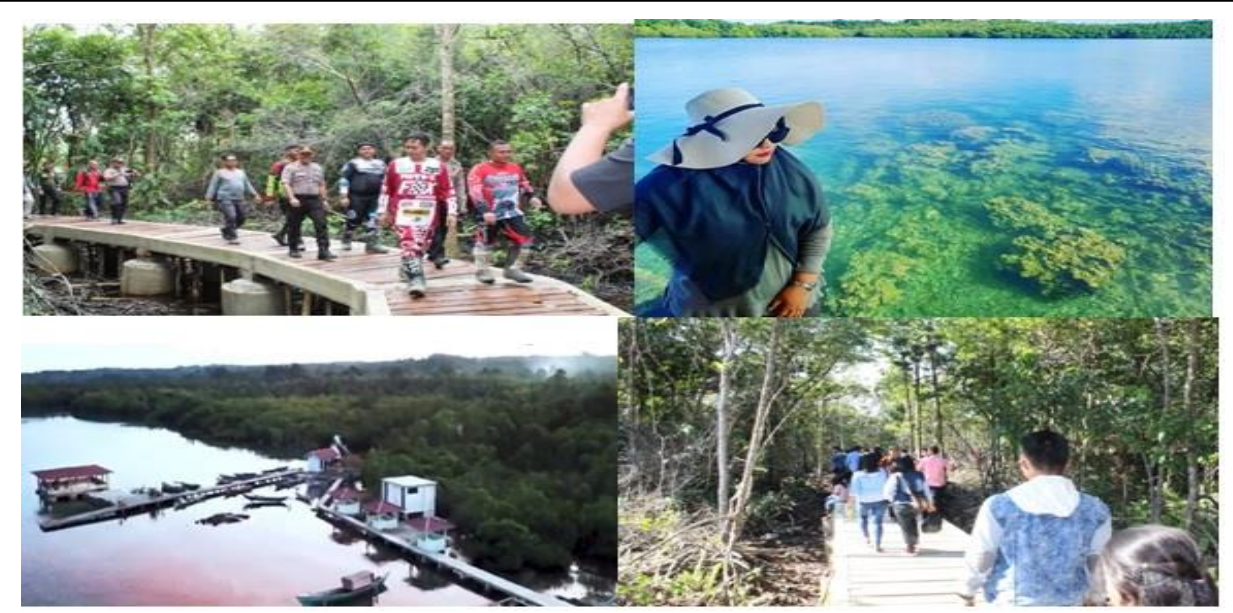

Gambar 1. Keadaan ekowisata mangrove Desa Sisarahili Teluk Siabang Kecamatan Sawo Kabupaten Nias Utara

Ekowisata yang berbasis hutan mangrove Desa Sisarahili Teluk Siabang ini telah dimulai dibuka mulai pada awal Bulan Januari s/d Pertengahan Maret 2020. Pengunjung yang datang baik lokal maupun dari luar. Dari hasil pemantauan perkiraan pengunjung lokal dan sekitar Desa \pm 1.000 org/bln, Sedangkan dari luar Desa \pm 5.000 org/bln. Pengunjung yang datang melonjak pada hari sabtu dan hari minggu serta hari besar/libur. Beberapa hal yang dilakukan oleh Pemerintahan Desa bersama dengan kelompok sadar wisata yang sampai saat ini 20 orang untuk menjaga kelestarian, ketertiban dan keamanan pengunjung yaitu 1). Sampai saat ini belum dipungut biaya apapun kepada pengunjung baik parkir maupun fasilitas lainnya. 2). Masyarakat desa tetap menjaga keramahan kepada pengunjung. 3). Pemerintah Desa tetap memantau dan memperhatikan keamanan. Salah satunya : Dilarang menjual dan membawa minuman beralkohol di lokasi wisata. 4). Pemilik warung di lokasi wisata, tiap hari Senin melaksanakan pemungutan sampah utk menjaga kebersihan.

Tingkat pendidikan masyarakat yang relative rendah dan sebagian besar sebagai nelayan dan petani, sangat sulit bagi mereka untuk bangkit dan belajar sendiri bagaimana menjadikan wisatara mengrove tersebut menjadi potensi ekowisata. Kondisi ini sudah mulai dapat diperbaiki dengan diversifikasi mata pencaharian. Masyarakat Desa Sisarahili Teluk Siabang sebagian mulai beralih ke sektor pariwisata karena adanya potensi dalam pemanfaatan hutan mangrove yang terdapat di desa tersebut. Setelah potensi wisata ini telah dibuka sudah ada sekitar 20 keluarga yang memenuhi kehidupan ekonomi keluarga dari hasil jual makanan dan jasa bagi pengunjung yang datang. Lokasi pengabdian ini dilakukan menempuh jarak yang cukup jauh dari Perguruan Tinggi Pengusul namun masih dalam satu provinsi yaitu Sumatera Utara sesuai dengan Lampiran lokasi mitra. Tujuan dari pengabdian kepada masyarakat ini adalah meningkatkan publikasi dan promosi ekowisata mangrove berbasis website dan sosial media untuk meningkatkan jumlah pengunjung baik lokal sekitar desa, dari luar desa maupun mancanegara.

\section{METODE PELAKSANAAN (METHODS)}

Kegiatan ini dilaksanakan dengan mengedepankan implementasi teknologi informasi untuk meningkatkan publikasi dan promosi. Teknologi informasi yang didalamnya terdapat website/laman dan juga media sosial. 
Metode yang akan dilakukan pada pelaksanaan pengabdian ini adalah:

1. Mendapatkan informasi awal berkoordinasi dengan mitra.

2. Membuat rancangan website/laman dan sosial media menggunakan informasi awal sebagai konten publikasi dan promosi.

3. Memberi penjelasan dan penyuluhan tentang pentingnya penerapan media teknologi informasi sederhana pada proses produksi informasi sehingga menjadi layanan promosi dan publikasi dapat lebih maksimal.

4. Menyiapkan SOP tentang pentingnya penggunaan teknologi informasi.

5. Memberikan penyuluhan tentang pentingnya kerjasama kelompok sadar wisata pada proses pengelolaan manajemen khususnya publikasi dan promosi.

6. Pengisian data yang berkelanjutan.

\section{HASIL DAN PEMBAHASAN (RESULT AND DISCUSSION)}

Perancangan dan pengisian data sesuai dengan informasi yang dikelola oleh tim pengabdian sebagai konten dalam promosi dan publikasi telah diselesaikan. Website atau laman dan sosial media dirancang lebih mudah dan interaktif, sehingga dapat digunakan dengan mudah oleh pengguna yang telah disiapkan oleh mitra. Layout website/laman dan sosial media dapat dilihat pada Gambar 2 dibawah ini.

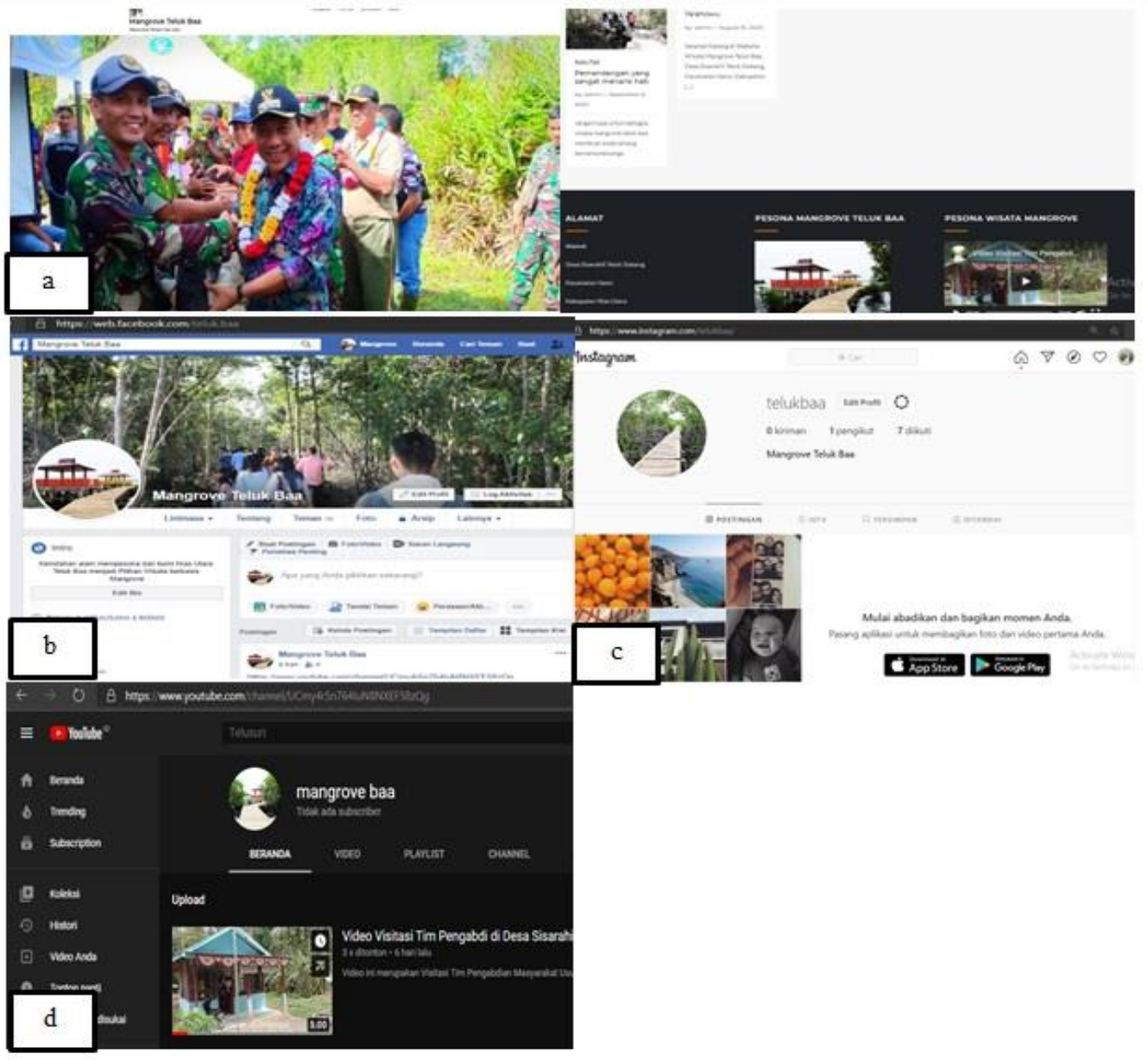

Gambar 2. Layout a. Website/laman b. Facebook c. Instagram d. Youtube 
Selain publikasi dan promosi melalui media sosial yang digunakan untuk menunjang promosi wisata mangrove, tim pengabdian juga melaksanakan sosialisasi kepada masyarakat disekitar wilayah dan kepada tim kelompok sadar wisata, serta kepala desa Sisarahili teluk Siabang. Kegiatan sosialisasi tersebut dilaksanakan dalam dua versi yaitu dengan mengadakan kunjungan secara langsung ke lokasi pengabdian masyarakat ; dan secara daring disebabkan oleh situasi pandemi covid19. Dalam sosialisasi tersebut tim pengabdian menyampaikan beberapa hal yang perlu dilaksanakan baik dari sisi kelengkapan sarana dan prasarana juga peningkatan pengetahuan masyarakat. Kegiatan sosialisasi dapat dilihat pada Gambar 3 dibawah ini.

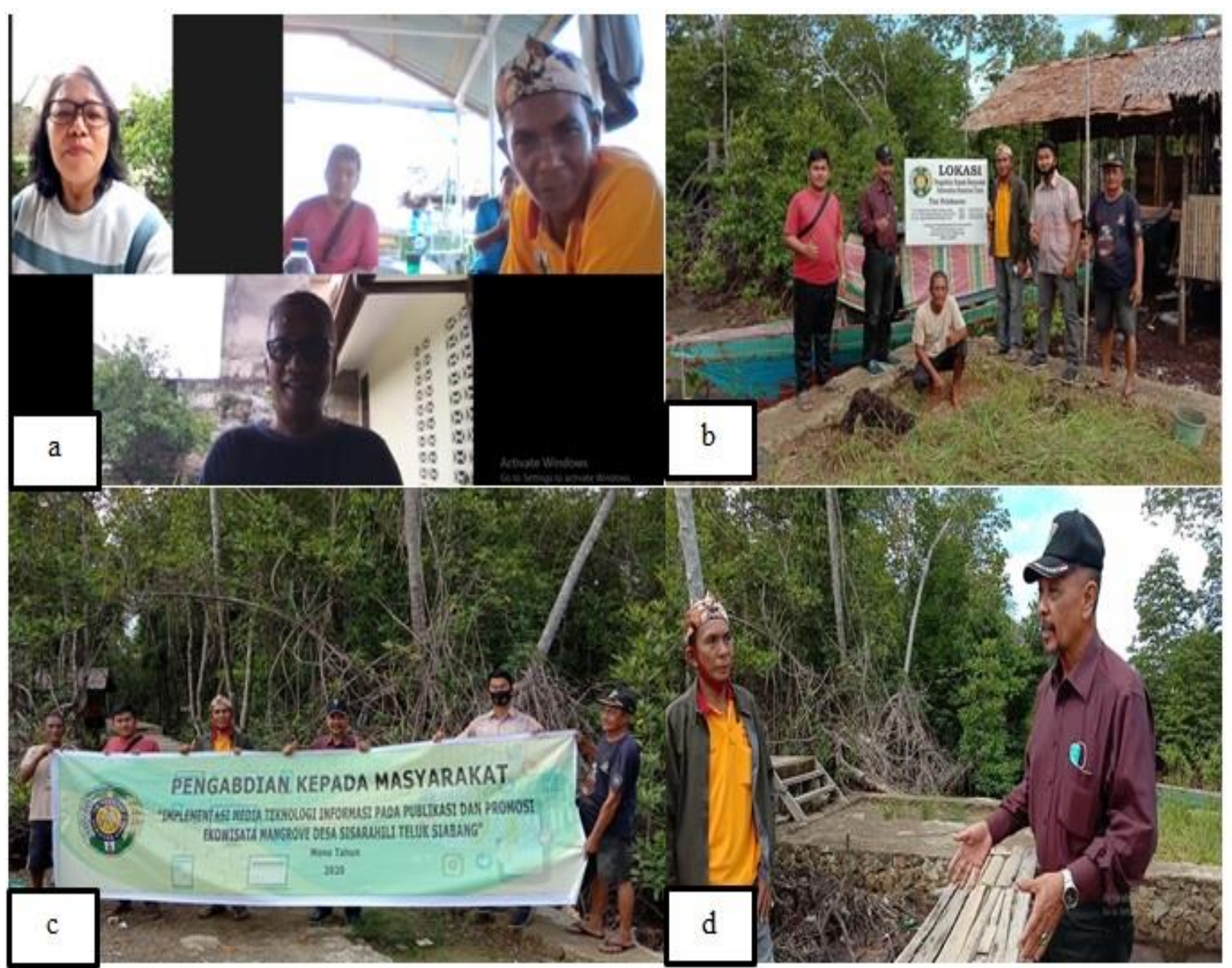

Gambar 3. a. Sosialisasi via daring (zoom) bersama mitra b. Peletakkan plank pengabdian c. Penyampaian spanduk pengabdian d. Penyuluhan di lokasi mitra

Dalam proses pelaksanaan pengabdian masyarakat tim pengabdian juga menyampaikan kuesioner untuk mendapatkan data tentang bagaimana pengunjung mendapatkan informasi tentang wisata mangrove teluk Ba'a. Kuesioner diberikan kepada pengunjung selama 2 hari kunjungan lapangan yang dilakukan oleh team pengabdian masyarakat.

Hasil survey dapat dilihat pada Gambar 4 dibawah ini. 


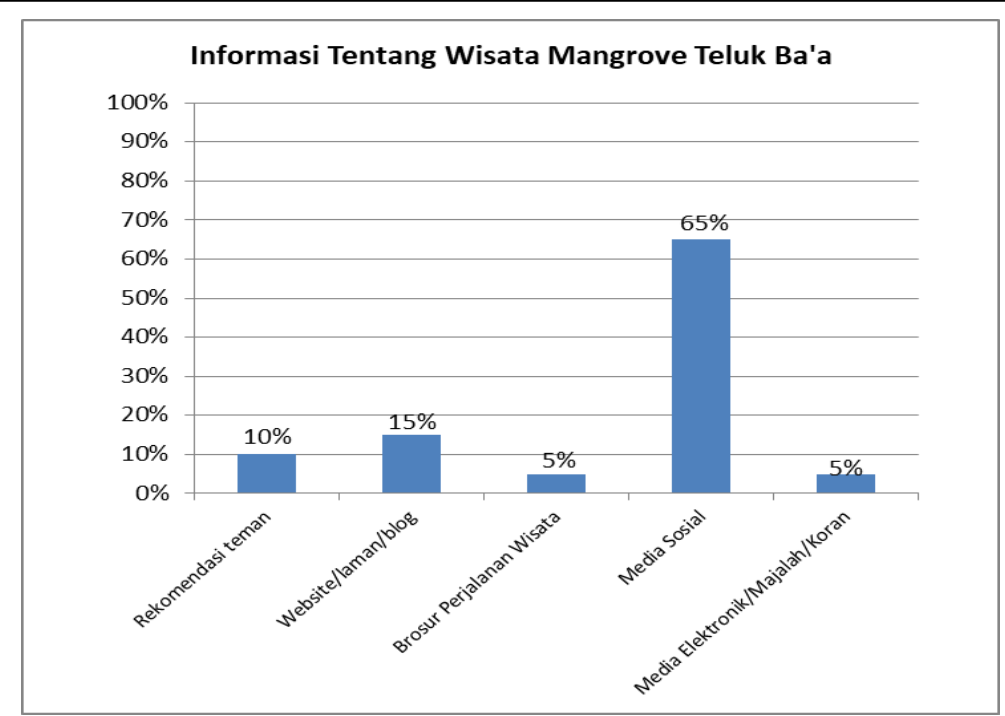

Gambar 4. Persentase pengunjung mendapatkan informasi lokasi wisata mangrove teluk Ba'a

Hasil survey menunjukkan bahwa sebanyak $65 \%$ dari pengunjung memperoleh informasi tentang wisata mangrove teluk Ba'a yang ada di kecamatan Sawo dari media sosial, dan $15 \%$ dari website/laman, dan lainnya memperoleh informasi dari media cetak dan masyarakat yang berada di sekitar hutan mangrove. Untuk itu perlu ditingkatkan upaya untuk memperluas jangkauan penyebaran informasi dan konten publikasi mengenai wisata mangrove teluk Ba'a untuk meningkatkan jumlah pengunjung. Disamping itu perlu dikembangkan program pemberdayaan masyarakat setempat agar meningkatnya jumlah pengunjung berdampak pada peningkatan kesejahteraan masyarakat.

\section{KESIMPULAN}

Pelaksanaan pengabdian masyarakat ini tim menyimpulkan bahwa :

1. Sosialisasi dan penyuluhan sangat penting untuk menambah wawasan dan pengetahuan sumber daya manusia (kelompok sadar wisata) dan pemerintah (kepala desa) untuk mengelola wisata mangrove menjadi lebih baik.

2. Pentingnya teknologi informasi baik melalui website/laman dan media sosial dalam meningkatkan promosi dan publikasi, sehingga pengunjung mendapatkan informasi yang lebih cepat mengenai wisata mangrove di teluk $\mathrm{Ba}$ 'a.

3. Berdasarkan survey yang telah dilakukan, sebanyak $65 \%$ pengunjung mendapatkan informasi tentang wisata mangrove teluk ba'a dari sosial media dan $15 \%$ dari website/laman sedangkan $20 \%$ lainnya pengunjung mendapatkan informasi dari teman, koran online dan masyarakat sekitar lingkungan wisata mangrove.

4. Waktu yang bersamaan dengan pelaksanaan pengabdian ini adalah sedang berlangsungnya pandemi COVID19, sehingga pengunjung pada lokasi kegiatan menurun. Diharapkan setelah pandemi COVID19 selesai, kunjungan dapat kembali normal dan jumlah pengunjung dapat lebih meningkat lagi.

\section{UCAPAN TERIMAKASIH}

Tim pengabdian menyampaikan terimakasih kepada Rektor Universitas Sumatera Utara melalui lembaga pengabdian masyarakat atas program mono tahun dana NON PNBP 
Universitas Sumatera Utara nomor 287/UN5.2.3.2.1/PPM/2020. Tim juga menyampaikan terimakasih kepada mitra pada kegiatan pengabdian ini.

\section{DAFTAR PUSTAKA}

DV, P. (2010). Kebijakan pengelolaan hutan mangrove berkelanjutan di Kabupaten Seram Bagian Barat. Institut Pertanian Bogor.

F Guebes, D., LP, J., D Nitto, D., Jo, B., D Seen, L., \& N, K. (2005). How effective were mangroves as a defense againts the recent tsunami? Current Biology, 15(12), R443R447.

Lalo, R. (2003). Kajian ekologi - ekonomi dalam pengelolaan ekosistem mangrove secara lestari di Kawasan Pesisir Banawa Selatan Kabupaten Donggala. Institut Pertanian Bogor.

Mendrofa, S. (2014). Struktur vegetasi mangrove di Kawasan Pesisir Desa Lasara Sawo Kecamatan Sawo Kabupaten Nias Provinsi Sumatera Utara. Institut Pertanian Bogor.

Zai, M., Arlius, \& Suparno. (2014). Kajian zonasi kawasan konservasi perairan daerah Kabupaten Nias Utara. OJS Bung Hatta. 